\title{
The emerging health paradigm in the 21st century: the formative first 1000 days of life
}

\author{
Jose Miguel De Anguloa, Luz Stella Losada ${ }^{b}$ \\ ${ }^{a} \mathrm{MD}, \mathrm{MPH}$, Regional Director for Latin America, MAP International, Bolivia \\ ${ }^{\mathrm{b}} \mathrm{MHPE}$, Community Health Specialist, MAP International, Bolivia
}

\begin{abstract}
During the 20th Century Western society's thinking regarding health and wellbeing underwent profound and rapid changes. Towards the end of the century, a health paradigm based on social health determinants emerged, providing a strong foundation for influencing priorities in global health. In this paper we will present evidence that supports a new paradigm. It avers that human health and development is founded on infants' brain architecture and their capacity to transform the brains and lives of adults. Neuroscience now shows how the brain architecture of the person becomes established during the intrauterine period and the first two to three years of life. This brain architecture determines the capacity of the organism to self-regulate its biological, emotional, cognitive, and interactional processes with the environment. The more robust this brain architecture, the more potential and capability that individual has to enjoy physical, emotional, and mental health as well as his/her capacity to contribute to the health and wellbeing of others. We hold that the transformative value of infants to society is biblical. This new understanding can generate a shift towards a focus on early infancy as the best strategy to foster development of healthy and sustainable societies.
\end{abstract}

\section{Introduction and Overview}

The 20th Century saw thinking concerning health and wellbeing undergo profound and rapid changes. Two health paradigms based on disease management influenced much of the theory and practice surrounding health in the western world. ${ }^{1}$ Both paradigms contributed to the alleviation of suffering and ill health. However, both showed an inadequacy to foster health at the level of society. Towards the end of the 20th century, a third and broader paradigm based on social health determinants emerged, fostering a shift from the causes of pathology to what produces health and wellbeing. This social health determinants paradigm provided a foundation for a fourth paradigm that is positioning itself in global health thinking today. ${ }^{1}$ This newly emergent paradigm builds on the experiences and advances achieved during the 20th Century, but shifts the focus to the architectural development of infants' brains and their ability to transform the brains of adults.

The social health determinants paradigm what we call the third paradigm - placed its hope in institutions and new systems as the source of social

Nov 2016. Christian Journal for Global Health, 3(2): 113-128. 
change and transformation. This was the approach that would resolve the inequities and lack of access to resources and livelihoods that maintain large sectors of society in poverty and vulnerability to ill health. The paradigm expected that institutions and systems held the solutions and had the power to create needed transformations. Although social health determinants indeed played a role in the health and wellbeing of communities and nations, the paradigm missed the mark by excluding an important element of human reality. This missing element has become evident as a result of a new understanding of social development and social dynamics involving the development of the infant's brain.

The core concept here is that society can only become healthy when human beings develop robust and healthy brain architecture during the first days of life. This paper reviews evidence from neuroscience research demonstrating that being born human does not necessarily ensure that a child will become humane. Rather, the ability to live harmoniously with other humans and with nature in a meaningful and healthy way are linked to the infant brain's capacity to understand others, to care, to share, to listen, to value, and to be empathetic. The foundation of these characteristics is established in early infancy by the experience of being cared for, shared with, listened to, valued, and nurtured. Humane caregiving fosters a brain architecture that is able to express our capacity to be humane. Inhumane caregiving erodes that human's capacity to be humane.

This paper proposes a new paradigm that human health and development is founded on the infants' brain architecture and the infants' capacity to transform the brains and lives of adults. The development of infants' brain architecture and perturbations in these processes can have long-term effects on the brain's structural and functional capacity. This opens a different way of understanding human behavior and how society functions. . $, 3,4,5,6,7,8,9^{-1}$

We will demonstrate how government and institutions need to focus on prenatal and early infancy programs and how to provide the best possible support to parents in order to fulfill their parental responsibilities for the $21^{\text {st }}$ century if we want to develop a more humane and just society for all. The Report of the Commission on Social Determinants of Health from the World Health Organization "Closing the gap in a generation" clearly states that we will not be able to overcome the large inequalities in the planet unless we focus on early child development (ECD). ${ }^{10}$ In the section of "A more comprehensive approach to the early years in life," the report bases its arguments on research findings like these:

The science of ECD shows that brain development is highly sensitive to external influences in early childhood, starting in utero, with lifelong effects. The conditions to which children are exposed, including the quality of relationships and language environment, literally 'sculpt' the developing brain (Mustard JF (2007). Experience-based brain development: scientific underpinnings of the importance of early child development in a global world. In: Young ME, Richardson LM, eds. Early child development: from measurement to action. Washington, DC, World Bank, pp. 43-71). . . Healthy development during the early years provides the essential building blocks that enable people to lead a flourishing life in many domains, including social, emotional, cognitive, and physical well-being (ECDKN [2007a]. Early child development: a powerful equalizer. Final report of the Early Child Development Knowledge Network of the Commission on Social Determinants of Health. Geneva, World Health Organization.). . . Many challenges in adult society have their roots in the early years of life, including major public health problems such as obesity, heart disease, and mental health problems. Experiences in early childhood are also related to criminality, problems in literacy and numeracy, and economic participation. ${ }^{10}$

Because children's brains are substantially changed by experiences during pregnancy and the first two years, there is a window of opportunity for 
programs that promote their development as healthy and productive citizens. A child's quality of life as well as the contributions that the child eventually makes to society as an adult can be traced to his or her first years of life and how that child's parents provided appropriate care. ${ }^{11,12}$ If the infant has secure attachments and support for growth in language, motor skills, adaptive abilities, and social-emotional functioning during the first 1000 days of life (including the intrauterine period), the child is more likely to succeed in school, develop healthy relationships, and contribute later in life to society. ${ }^{13}$ There are "sensitive periods," or windows of opportunity for certain specific developments to take place. $^{14,15}$ For example, the sensitive period of phonology is from the sixth month of fetal life through the first year. ${ }^{16}$ Similarly, proficiency of language is achieved before 18 months of age. Significant disparities in language-processing efficiency exist depending on whether parents talk more and use richer vocabulary and gestures in interactions with infants. ${ }^{17}$ The zero-to-three age period is vital for the production and subsequent retention of synapses; inadequate interactions during this period can have large and lasting negative effects on subsequent development. ${ }^{18}$ The maternal effect on stress responses in the offspring can directly affect gene expression (epigenetics) controlling the development of the brain and nervous system. ${ }^{19}$

Current research confirms how critical it is to provide infants with rich environments and rich interaction with their parents. For example, when analyzing the capacity to develop and use language, researchers have found significant disparities in vocabulary and language processing efficiency already evident at 18 months when comparing infants from higher- and lower- socio economic status families. By 24 months, there was a six-month gap between socio economic status groups in their processing skills, something that is critical for language development during the rest of their lives. ${ }^{20}$ Other studies show that the so called "Early Catastrophe: The 30 Million word gap by Age 3" persists and increases throughout life, having a broad impact on cognitive development that includes nearly every aspect of language ability. ${ }^{21,22,23}$ This reveals an urgent social need for public policies and programs that foster quality parent-child interactions and provide guidance in how to build more supportive communities. The importance of the first 1000 days should inform the development of public health policies and programs aimed toward the family. ${ }^{24}$ It is also a call for churches, NGOs and institutions engaged in community development to play a stronger role in supporting comprehensive child development.

During the intrauterine period and the first two to three years of life, development of brain architecture determines the capability of the human organism to regulate its biological, emotional, cognitive, and interactional processes with the environment. The more robust an individual's brain architecture, the more potential and capability that individual has to enjoy physical, emotional, and mental health at the personal level and to contribute through his/her life to the health and wellbeing of others.

Targeting public policies and programs specifically to pregnant women and parents with infants can be a shortcut to proposals to modify social health determinants. Even countries that have had successes with social health determinants have not necessarily produced healthy families and communities. Many people in such countries are not very healthy, but are high consumers of medicines with frequent diagnoses of diseases that require costly resource expenditures and continue to exhibit risky behaviors. They may have overcome most problems of material poverty, but face a relational poverty that generates serious mental and physical health problems. ${ }^{25,26,27,28}$ The capacity of the individual to construct meaningful healthy relationships determines health through a variety of mechanisms. These include empathy and commitment to engage with others' needs and problems, increased collective creativity, agreement on common goals for the 
wellbeing of all, commitment to produce in teams and groups, and engagement in transformative processes aimed at reducing social, economic, and political factors that undermine the wellbeing of all.

Some studies, such as the "Jamaica study" with a 20-year follow-up, show that even very impoverished communities can have physically and mentally healthy children if parents develop basic skills to change the way adults see, listen, and interact with infants. ${ }^{29,30}$ Other examples of effective programs that focus solely in the child instead of pursuing broad changes related to social health determinants are Abecedarian, High/Scope Perry Preschool programs, and Early Head Start, among others. $^{31,32,33,34,35}$ Although some discussions on social health determinants previously acknowledged early infancy as one more variable to consider in making societies healthier, current research shows that early infancy plays a central role.

Mental representations of the fetus in pregnant women have implications in the ways mothers view themselves, how they view the fetus, and how the two interact. Paternal - fetus attachment also influences the way that infants will be treated. ${ }^{36,37,38}$ Negative, idealized, or incoherent prenatal representations predict postnatal parent-child relationship problems during the child's first year. A mother's and father's sensitivity is linked to their ability to perceive, interpret, and affectively share and mirror their young child's emotional states. This leads to a high capacity for responding to infant distress. ${ }^{39,40}$ Modification of mental representations of her fetus with a pregnant woman living in impoverished conditions affects the future of that mother, her mental health, and the way she interacts with the infant. This can change the child's future without experiencing other types of interventions that involve social determinants. $^{41,42,43,44,45}$ These studies show how it is possible to bring radical changes about in the life of future generations without necessarily waiting until social health determinants can be transformed.

However, poverty is not necessarily the major cause of poor socio-emotional development in infants. Maternal preconceptions about parenting are predictors of a child's temperament, sensitivity, and empathy with good pro-social behaviors, even for mothers belonging to low socioeconomic groups. ${ }^{46}$ Secure attachment is a powerful force creating an "enduring affective tie" that has a "strong reciprocal" quality (parent-to-infant and infant-to-parent) that generates changes in all those involved. ${ }^{47}$ The power of brains to shape each other in paternal/maternal fetus/infant interactions was unknown until this century.

If social and family systems can be transformed to express full respect and empathy for infants and to respond to their efforts to communicate needs and interests, those infants will develop robust brain architecture. Infants that have profound and consistent experiences of empathy during their first months of life will develop a strong capacity to experience empathy and love toward those with whom they interact in other phases of their lives. This in turn produces a framework or platform that will enable these individuals to establish trusting and responsible relationships with others, with God, and with nature. And though social health determinants play a role in this development process, strategically focusing on infants' brain development will help to bring about the transformation of those systems responsible for social health determinants.

\section{Centrality of Infant Brain Development}

\section{in the Emerging Health Paradigm}

There is accumulating evidence that identifies early infancy as central to health and development. The publication, INBRIEF, "The Foundations of Lifelong Health," provides an extensive review of evidence accumulated during the last decade:

A vital and productive society with a prosperous and sustainable future is built on a foundation of healthy child development. Positive early experiences provide a foundation for sturdy brain architecture and a broad range of skills and learning capacities. . . Advances in neuroscience, molecular biology, and genomics have converged on three 
compelling conclusions. Early experiences are built into our bodies, creating biological "memories" that shape development, for better or for worse. Toxic stress caused by significant adversity can produce physiological disruptions that undermine the development of the body's stress response systems and affect the architecture of the developing brain, the cardiovascular system, the immune system, and metabolic regulatory controls. These physiological disruptions can persist far into adulthood and lead to lifelong impairments in both physical and mental health. ${ }^{48}$

Dr. Jack P. Shonkoff, the Chair of the National Scientific Council on the Developing Child, presented the conclusions of multiple years of research into the science of early childhood development. These were his main points:

The healthy development of all young children benefits all of society by providing a solid foundation for responsible citizenship, economic productivity, lifelong physical and mental health, strong communities, and sustainable democracy and prosperity... Relationships are the "active ingredients" of early experience. Nurturing and responsive relationships build healthy brain architecture that provides a strong foundation for learning, behavior, and health. When protective relationships are not provided, elevated levels of stress hormones (i.e., cortisol) disrupt brain architecture by impairing cell growth and interfering with the formation of healthy neural circuits. $^{49}$

Research conducted and published by the U.S. Centers for Disease Control on "The Relationship of Adverse Childhood Experiences to Adult Health Status" pushes us to completely rethink the traditional way of understanding the "history of diseases" (from the moment of exposure to causal agents until recovery or death). This research opens the door to a new way of understanding why diseases are present in society. Dr. Vincent J. Felitti and Robert F. Anda are the authors of The Adverse Childhood Experiences (ACE) Study. ${ }^{50}$ This large study examined the health, social, and economic effects of adverse childhood experiences over the lifespan of 18,000 participants in the USA. An individual's childhood experiences shaped the epidemiological profile of that child in his/her adult life, as well as the epidemiological profile of the entire nation.

Adverse childhood experiences are the most basic cause of health risk behaviors, morbidity, disability, mortality, and healthcare costs . . . Many chronic diseases in adults are determined decades earlier, in childhood. ${ }^{51}$

The relationship of adverse childhood experiences and mental health are shown in the use of psychotropic medications in adults:

The strong relationship of the ACE Score to increased utilization of psychotropic medications underscores the contribution of childhood experience to the burden of adult mental illness. Moreover, the huge economic costs associated with the use of psychotropic medications provide additional incentives to address the high prevalence and consequences of childhood traumatic stressors. ${ }^{52}$

Linked to mental illness is the lack of empathy that children experience. Empathy underlies trust, altruism, collaboration, love, and solidarity. A failure to empathize is a key part of most interpersonal and social problems, including crime, violence, war, racism, child abuse, and inequity, among others. Empathy is associated with pro-social behavior, and expression of sensitivity and responsiveness by parents. Infants experiencing empathy thorough the care and love of parents with secure attachment will display empathy toward other people throughout their lives. Insecure and disorganized attachments obstruct the cultivation of empathy, which, on a broad social level, can easily lead to a society in which no one wants to live because of the cold, violent, chaotic, and terrifying interactions of all against all. Parental sensitivity, responsiveness, and proactive involvement with infants and toddlers play a key role in their

Nov 2016. Christian Journal for Global Health, 3(2): 113-128. 
capability to express empathy and prosocial behaviors in future stages of their lives. ${ }^{53,54,55,56,57,58,59,60}$

\section{The Power of the Infant's Brain to Transform the Parents' Brains}

Because brain architecture is constructed during pregnancy and especially during the first two years of life, parents play a critical role in the generation of a robust brain architecture. Research also shows how the infant's brain connects with, synchronizes with and modulates the parent's brain and equips the parents to become sensitive and responsive to the infant`s expressions of her developmental needs. ${ }^{61}$

Appropriate interaction with infants generates changes in the father's and mother's brains, fostering plasticity and new ways of thinking, interacting, and engaging with the world. For example, in bi-parental mice (raised by father and mother), there is increased neurogenesis in the paternal olfactory bulb in the prefrontal cortex (PFC) and hippocampus. These male mice can even recognize their offspring as adults if they interacted with their infant pups. ${ }^{62}$ Other research shows how engaged parents experience plasticity and how caregiving impacts their brain. Its conclusion is that

... the brains of parents are clearly different from those of non-parents, having been changed by the presence of offspring and corresponding hormonal fluctuations. Available evidence suggests that structural reorganization occurs in the hippocampus and PFC (of mothers and fathers). ${ }^{63}$

The baby's interaction with the father "rewires the daddy brain ... Love spurs the very growth of the parental brain and even causes new brain cells to develop ... Those parental impacts on your brain begin long before birth, setting into motion major factors for your future relationships. $" 64$

In the first few days after birth, changes occur in the brains of both the father and the baby, depending on whether the father is engaged with the child or not. Neuroscientists have helped us to understand the father-child bond, and have found a hook that makes a father stay involved after birth. ${ }^{65}$ There are many new scientific findings from neuroscientists, animal behaviorists, geneticists, and developmental psychologists, among others, that show the profound physiological connections between children and fathers, and the profound changes this interaction generates. ${ }^{66.67 .68}$ These epidemiological studies on adverse experiences and lack of empathy — paired with research on the ingrained capacity of the infant's brain to tune, modulate, and synchronize the adult's brain bringing plasticity and changes in the way the adult thinks, feels, and acts - are creating fascinating new ways to understand humans and society. The application of the science of early childhood development creates opportunities for very innovative health and development programs. ${ }^{69}$

\section{Determinants of Infant Brain}

\section{Development}

Parental education and especially family income play a very important role in the type of brain architecture an individual is going to have. Income strongly relates to brain structure among the most disadvantaged children. Socioeconomic disparities are associated with differences in cognitive development and, therefore, with the type of life those individuals will have. These relationships were most prominent in brain cortex regions supporting language, reading, executive functions, and spatial skills; cortex surface area mediated socioeconomic differences in certain neurocognitive abilities. Among children from lower income families, small differences in income were associated with relatively large differences in cortex surface area. ${ }^{70,71,72}$

Programs can make a large difference by engaging with impoverished sectors of society:

Certainly both school-based and home-based interventions have resulted in important cognitive and behavioral gains for children facing socioeconomic adversity, and small increases in family earnings in the first 2 years of a child's life may lead to notable differences in adult circumstances. ${ }^{73}$ 
The Report of the Task Force on the Family from the American Academy of Pediatrics states, "Families are the most central and enduring influence in children's lives. . . The health and well-being of children are inextricably linked to their parents' physical, emotional and social health, social circumstances, and child-rearing practices." ${ }^{, 74}$ Families need the support of public policies and programs that enables them to care for five key determinants of healthy brain architecture develop- ment: a) proper nutrition and access to health services, b) psycho-emotional nourishment (with strong bonding and secure attachment), c) cognitive nourishment, d) capacity development for selfagency, and e) safe and enriching environments (Figure 1). ${ }^{75}$ These five determinants of brain architecture development synergistically interact with each other, and the deficiency of one or more of these determinants may lead to serious impairments in a person's life and health.

Figure 1: The Central Causal Story ${ }^{75}$

\section{The Central Causal Story behind a healthy adult with successful} educational accomplishment \& economic productivity that effectively contributes to a democratic inclusive \& productive society PERSONAL HEALTH DETERMINANTS

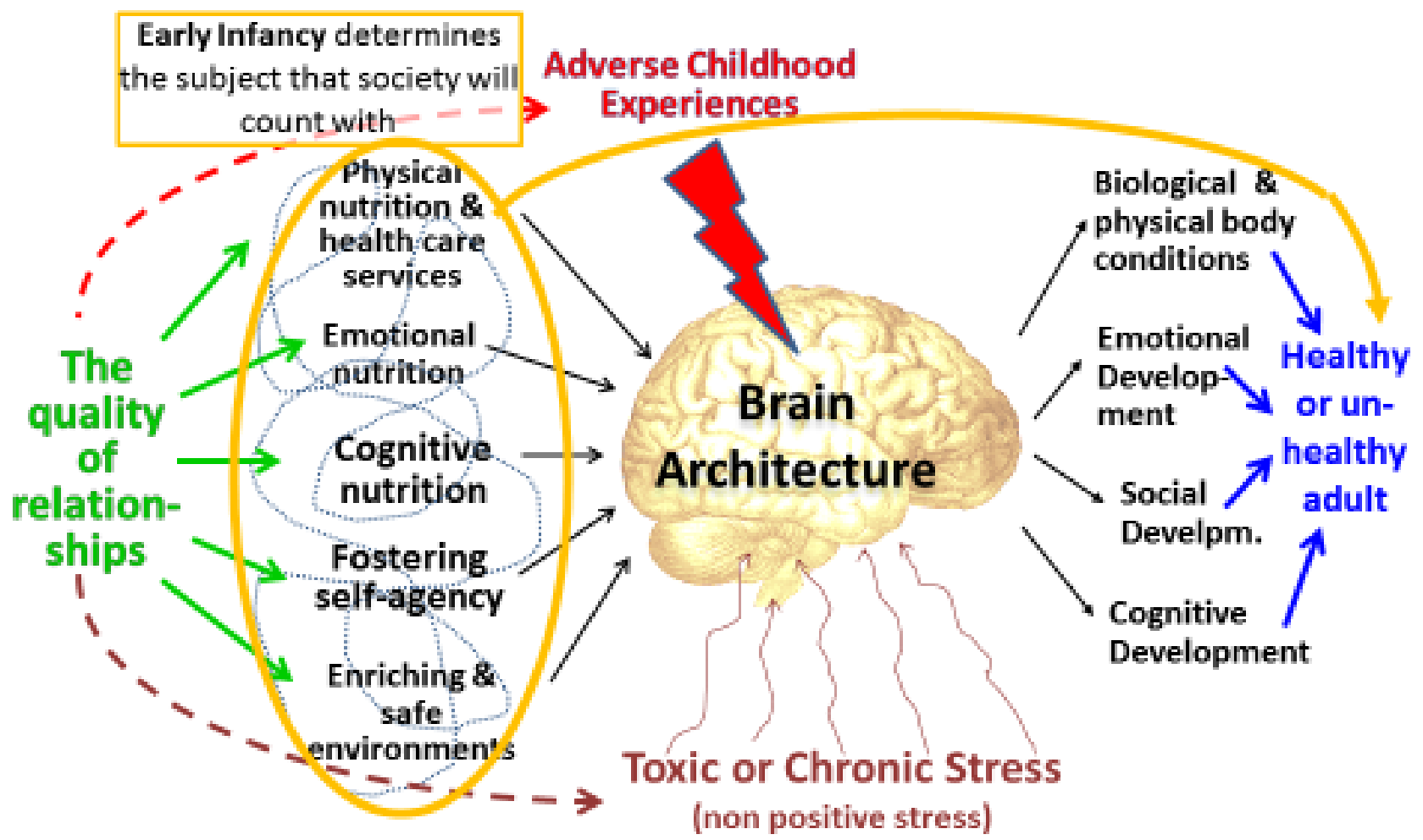

Developing countries will not be able to overcome poverty, violence, and mental and physical illness unless there is a paradigmatic shift concerning where efforts should be focused. The lack of commitment to care for the determinants of infant brain development will maintain most of the problems

Nov 2016. Christian Journal for Global Health, 3(2): 113-128. 
developing societies face today. The first annual report of Scotland's civil society coalition formed by 98 institutions and many researchers published on

December 2014 states:

Our coalition is built upon three realities:

1. Far too many babies and toddlers have their immediate wellbeing compromised (and their life chances diminished) by being 'dealt a bad hand' during the crucial developmental period from conception through age two. Although later interventions can be very helpful, there is no second chance to make a good first impression on the brains, bodies and behaviors of babies and toddlers.

2. Our society and systems remain too reactive - usually waiting until children have already been adversely affected and then rushing in to 'clean up the mess.' In 2011, the Christie Commission calculated that a huge amount of Scotland's resources around $40 \%$ of all public expenditures - are spent dealing with problems that could have been prevented. This remains true today.

3. 'Closing the gap' - in terms of health outcomes education attainment and other inequalities - is absolutely the right thing to do. However, 'preventing the gap' from opening in the first place is the urgently needed new priority. This requires dramatically increased investment in, and improved action during, the first 1,001 days of life (from pre-birth to pre-school) ${ }^{76}$

This coalition acknowledged that governments and societies need to focus exclusively on two issues: the primary prevention of harm (i.e., keeping bad things from happening in the first place); and, caring the first 1,001 days of life (from pre-birth to preschool). That is why they chose as title of the report: "Social Justice Begins with Babies."

\section{The New Open Horizon}

Governments and institutions, especially churches, working with families with infants need to know about the key personal health determinants to develop robust and healthy brain architecture for a healthy and meaningful life. Infants keep coming into most families and communities of all cultures and socioeconomic conditions, and with them enter incredible opportunities to see God's power transforming those families through the infants. Nothing illustrates this better than Jesus' followers when they really cared about the future of society and the planet by focusing on caring for our children. Families need to have appropriate support to foster robust brain architecture in infants, so that those infants may develop their potential for learning, relationships, production, and engagement with nature and society in a meaningful and sustainable way. In this context, social determinants of health acquire a new dimension by redirecting them toward families' capacity to build healthy contexts that guarantee the adequate care of the personal determinants of health for infants. Nobelist James J. Heckman states:

A large body of empirical work at the interface of neuroscience and social science has established that fundamental cognitive and non-cognitive skills are produced in the early years of childhood, long before children start kindergarten. The technology of skill formation developed by economists shows that learning and motivation are dynamic, cumulative processes. Schooling comes too late in the life cycle of the child to be the main locus of remediation for the disadvantaged. Public schools focus only on tested academic knowledge and not the non-cognitive behavioral components that are needed for success in life. Schools cannot be expected to duplicate what a successfully functioning family gives its children. Parental environments play a crucial part in shaping the lives of children. ${ }^{77}$ 
The findings described here invite the consideration of a new health paradigm. New paradigms can be "disruptive innovations" opening up opportunities to see health work in a different way:

Taken together, current challenges invite radical new paradigms, which have been dubbed "disruptive innovations." Specifically, Bowder and Christensen have introduced the concept of disruptive innovations to describe how new radical paradigms can produce simpler, more convenient, more customizable, or cheaper ways of benefiting consumers who are currently being ignored by industry leaders. ${ }^{78}$

These considerations open the door to a new type of primary health worker with training focused on the intrauterine period and early infant development. Engagement with parents as soon as a pregnancy is identified would allow collaboration with other health professionals able to provide hope and confidence to the pregnant woman and young parents. Such a trans-disciplinary trained health worker could see the individual as a whole person beginning in the womb. He or she should also have the support of an inter-professional team that includes medical and mental health experts and professionals from the field of social work, child protection, economic development, etc.

These considerations also invite a rethinking of population control approaches to global health. Are new babies mouths to feed (burdens) or active agents of transformative change? We will not achieve population control by "demonizing an increase of baby numbers" but by facilitating the development of robust brain architecture in the new generation of children to produce strong self-agency, selfregulation, and a capacity to develop healthy relationships through life.

Churches have an opportunity to supplement research findings on brain development during pregnancy and the first two years of life with a theological perspective about why children are so linked to the Kingdom found in Scripture: "Truly I tell you, unless you change and become like little children, you will never enter the kingdom of heaven." (Matt 18:21), or Psalms 8:2 which announced that from the mouth of infants or sucklings God will display His power.

God called a marginal nation to be holy, to serve the Creator by carrying out his purposes and to be priests, as God's representatives before the world (Deut. 7:6-7; Ex. 19:6; Deut. 28:9-10). In these passages, one priestly role was to provide health; not simply biological health of individuals, but a holistic health that implies harmony with the Creator, with others, with social and political structures, and with nature. This was the meaning of shalom. One of the highest commitments a Jesus follower may have in any shalom ministry is to foster that shalom in the most critical period of human life: the intrauterine period and the first years. God desires shalom not only for the Hebrew nation but for all humankind. In John 20:21-23, Jesus appointed the Church to be not only the "object" of God's redemptive activity, but also the "subject," bringing God's salvation to all of humanity. The Church has been sent by the Lord and equipped by the Holy Spirit to continue what Jesus began during his ministry on earth.

Many passages in the Gospels show how salvation implies entering into Christ's Kingdom and beginning to produce the fruits of that Kingdom (Matt 4:23; Mark 1: 14-17; Luke 4: 18-21). Jesus clearly delegated to the Church the responsibility of bringing God's Kingdom to all places in the world in order to extinguish the empire of death (John 17:18; Luke 12:31-32). ${ }^{79}$ In order to fulfill the calling of partaking in the announcement of the Kingdom, people need first to learn more about that Kingdom by becoming like a child. Those who are willing to enter into the magnificent world of a child have the opportunity to learn profound truths that even thinkers and academics could not understand. When adults see and experience all an infant can do in the life of parents and other adults, they learn to understand the multiple languages infants use to communicate their needs and interests. When they also have developed skills to respond promptly, appropriately, and loving-

Nov 2016. Christian Journal for Global Health, 3(2): 113-128. 
ly to those infants, they experience a greater hope about God's moving in the world. As never before, humanity today has the opportunity to repent and join God's strategy for restoring shalom in individuals, families, societies, and nature, partaking of the emergence of these new types of human beings full of grace and empathy toward all.

\section{Final Words}

There is a new agenda in efforts for building healthy societies that requires governments, families, institutions, and societies in general to address the origins of what can make people healthy. As the Public Health Agency of Canada talking about "The greatest potential to positively influence health in the population" summarizes:

A population health approach maximizes its potential by directing efforts and investments 'upstream' to address root causes of health and illness. . Upstream investments are interventions aimed at the root causes of a population health problem or benefit. Root causes are often identified by determining the most immediate and direct causes, and working backwards from there. In many cases, upstream action addresses social, economic and environmental conditions. The population health approach is grounded in the notion that the earlier in the causal stream action is taken (i.e., the more upstream the action is), the greater the potential for population health gains and health-related cost savings. It is often true, however, that these root causes are more difficult to change, requiring more time, more resources and more will. ${ }^{80}$

This emerging new paradigm shows that the brain is not mature at birth, but rather organizes itself through experiences and through the interaction of genes that respond to the local environment and especially to the interactions with the "meaningful other." A person's potential to manifest God's image and likeness throughout life has a lot to do with the love and care that person experiences during infancy or with the neglect, intrusive interactions, and violence that person suffers during infancy. The primary responsibility of the family is to provide healthy conditions for infant brain development, because it will facilitate not only the development of healthy relationships with other fellows though their lives, but also to develop a genuine spirituality with the loving Heavenly Father. Our early development is like a very dynamic dance between the biology given us by God and our interactional experiences in our first years of life. The early years of a child's life critically impact a range of outcomes throughout life's course, especially the way in which that child will relate with other people.

Today's science and Jesus' teachings about infants open our understanding to an incredible new horizon that brings healing and hope to a world full of suffering and inequalities. The environment a young child experiences, especially the type of bonding he or she experiences, literally sculpts the brain and establishes the long-term trajectory for cognitive and social-emotional outcomes that will determine learning capacities and productive expressions throughout that child's life. If we want to improve outcomes in schools and in adult life, we must focus intently on the child's brain development during the early years. This new focus has profound implications for public policy, for family health, for nurturing environments for children, and for preschool programs. Investing in early childhood is a sound economic investment. In fact, it is the best investment society can make — not only for prevention of pathologies, social problems, and crime, but also for developing each child's highest human potential.

The previous findings are creating a new horizon, which in one or two generations could bring profound transformation to the way persons express their potential as human beings. Larger capacities to learn and to establish healthy relationships could come about without having to wait several generations to see modification of social health determinants. Impoverished communities could rapidly initiate transformational processes in their 
communities by raising citizens with a larger capacity for learning, greater ability to establish solid and enriching relationships, increased innovations and creativity, and skills for advocacy and effective interaction with government authorities and outside institutions. All of these things can rapidly create change with regard to the different social health determinants, as well as increase wellbeing for present generations.

As we are seeing, science is showing how comprehensive early infancy development during the first 1000 days of existence must become the first priority for private and public sectors if we want to construct healthy, peaceful, prosperous, and sustainable families, communities, and countries. ${ }^{81,82}$ Similarly from the theological point of view, we need to engage in one of the most urgent theological reflections on the Scripture passages dealing with infants and other teachings about children. It also requires a broader understanding of God's missionary strategy for entering into the drama of human history as a fragile living infant to bring hope. As Leonardo Boff stated talking about God's radically different logic: "Every boy wants to be a man; Every man wants to be a king; Every king wants to be god; Only God wanted to be a child." 83

The full comprehension of Jesus' ministry and sacrificial death cannot be achieved without the historical moment of God's incarnation as a vulnerable infant, and we will better understand this when we become humble and willing to enter into the world of the infant. God's tender love and patience can be beautifully understood by the tenderness and patience of infants' steadfast expression of love and grace regardless of the intrusive and neglecting behaviors of adults. When couples begin to discover the beauty and wholeness of their infant, they will begin to see their own beauty and wholeness as individuals, couples, and families, bringing resiliency to all the brokenness they have been receiving and carrying since their own infancy. Infants' endless forgiveness of adults' neglectful or intrusive and controlling behaviors, and disdaining of God's channel of grace, are living signs of God's obstinate love for us. Learning about what science is discovering in the child's brain allows us to have a new understanding of Isaiah 9:6: "For unto us a child is born." In this way, we can better experience the profound truth that we cannot find God, it is God who finds us, coming to us as a child - a poor, harmless, crying baby. Only those who become humble to God's logic of love and grace can really understand the option of the One who, in order to not be separated from His love for us, was willing to even leave His position of privilege to enter in our broken history and lives. Entering into the world of infants opens us to an immense sensitivity to God's incredible and gracious way to heal, to restore, and to bring shalom into our lives, families, and society. How different the life of individuals, families, and society will be when we understand that "if we change the beginning, we change the whole story!"

\section{References}

1. De Angulo JM, Losada LS. Health paradigm shifts in the 20th century. Christ J Glob Health. 2015;2(1):4958. http://dx.doi.org/10.15566/cjgh.v2i1.37

2. Oates J, Grayson A, editors. Cognitive and language development in children. Oxford: Blackwell Publishing; 2004.

3. Shonkoff JP, Phillips DA, editors. From neurons to neighborhoods: the science of early childhood development. National Research Council and Institute of Medicine; 2000.

4. Shonkoff JP, Garner AS, Siegel BS, Dobbins MI, Earls MF, Garner AS, et al. The lifelong effects of early childhood adversity and toxic stress. Pediatrics. 2012 Jan;129(1). http://dx.doi.org/10.1542/peds.2011-2663

5. Rutter M., 2007. Gene-environment interdependence. Dev Sci. 2007;10(1):12-8. http://dx.doi.org/10.1111/j.1467-7687.2007.00557.x

6. Grantham-McGregor S, Cheung YB, Cueto S, Glewwe Pl, Richter L, Strupp B, and the International Child Development Steering Group. Developmental potential in the first 5 years for children in developing countries. Lancet. 2007;369:60-70. http://dx.doi.org/10.1016/S0140-6736(07)60032-4 
7. Wachs T, Rahman A. The nature and impact of risk and protective influences on children's development in low-income countries. In Britto PR, Engle P, Super C, editors. Handbook of Early Childhood Development Research and Its Impact on Global Policy. New York: Oxford University Press; 2013.

8. Young ME. Addressing and mitigating vulnerability across the life cycle: the case for investing in early childhood. United Nations Development Programme, Human Development Report Office; 2014.

9. Leckman JF, Panter-Brick C, Salah R, eds. Pathways to peace: the transformative power of children and families. Strüngmann Forum Reports 15. Cambridge MA: MIT Press, 2014.

10. World Health Organization, Commission on social determinants of health. Closing the gap in a generation: health equity through action on the social determinants of health. Final Report of the Commission on Social Determinants of Health. Geneva, World Health Organization. 2008

11. Mustard JF. Investing in the early years: closing the gap between what we know and what we do. Department of the Premier and Cabinet c/o GPO Box 2343 Adelaide. - Crown - in right of the State of South Australia; 2008.

12. Mustard JF. Early brain development and human development. Encyclopedia on Early Childhood Development; 2010. http://www.childencyclopedia.com/documents/MustardANGxp.pdf

13. Halfon N, Inkelas M, Hochstein M. The health development organization: an organizational approach to achieving child health development. The Milbank Quarterly. 2000;78(3):447-97. [Milbank Memorial Fund, Published by Blackwell Publishers]. Available from:

https://www.ncbi.nlm.nih.gov/pmc/articles/PMC2751 167/pdf/milq_180.pdf

14. Ruben RJ. A time frame of critical/sensitive periods of language development. Acta Oto-laryngol.

1997;117(2):202-5 http://dx.doi.org/10.3109/00016489709117769

15. Wynder EL. Introduction to the report on the conference on the "critical" period of brain development; preventative medicine. 1998: 166-7.

16. Ruben RJ. 1997. A time frame of critical/sensitive periods of language development. Acta OtoLaryngologica. 1997;117(2). http://dx.doi.org/10.3109/00016489709117769
17. Weisleder A, Fernald A. Talking to children matters: early language experience strengthens processing and builds vocabulary. Psychol Sci. 2013;24(11):2143-52. http://dx.doi.org/10.1177/0956797613488145

18. Kotulak R. Inside the brain: revolutionary discoveries of how the mind works. Prevent Med. 1998;27:246-7. http://dx.doi.org/10.1006/pmed.1998.0281

19. Weaver IC, Cervoni N, Champagne FA, D'Alessio AC, Sharma S, Seckl JR, et al. Epigenetic programming by maternal behavior. Nat. Neurosci. 2004;7:847-54. http://dx.doi.org/10.1038/nn1276

20. Fernald A, Marchman VA, Weisleder A. SES differences in language processing skill and vocabulary are evident at 18 months [NIH-PA Author Manuscript]. Dev Sci. 2013 March;16(2): 234-48. http://dx.doi.org/10.1111/desc. 12019

21. Hart B, Risley TR. The early catastrophe: the 30 million word gap by age 3. American Educator. Spring, 2003.

22. Troyer M, Borovsky A. Childhood SES affects anticipatory language comprehension in college-age adults. Proceedings of the Cognitive Science Society. 2015.

23. Fernald A, Weisleder A. Twenty years after "meaningful differences," it's time to reframe the "deficit" debate about the importance of children's early language experience. Human Development. 2015;58:1-4. http://dx.doi.org/10.1159/000375515

24. Doyle O, Harmon CP, Heckman JJ, Tremblay RE. Investing in early human development: timing and economic efficiency. Economics and human biology. 2009;7:1-6. http://dx.doi.org/10.1016/j.ehb.2009.01.002

25. Divorces in England and Wales - 2011; Office for National Statistics, December 2012. Available from: http://www.ons.gov.uk/peoplepopulationandcommun ity/birthsdeathsandmarriages/divorce/bulletins/divorc esinenglandandwales/2012-12-20

26. McLeod BD, Wood JJ, Weisz JR. Examining the association between parenting and childhood anxiety: a meta-analysis. Clin Psychol Rev. 2007 Mar;27(2):155-72. [Epub 2006 Nov 16] http://dx.doi.org/10.1016/j.cpr.2006.09.002

27. McLeod BD, Weisz JR, Wood JJ. Examining the association between parenting and childhood depression: a meta-analysis. Clin Psychol Rev. 2007 Mar 12; 27(8):986-1003. http://dx.doi.org/10.1016/j.cpr.2007.03.001 
28. Green H, McGinnity A, Meltzer H, Ford T, Goodman R. Mental health of children and young people in Great Britain, 2004; Office for National Statistics. Available from: http://www.esds.ac.uk/doc/5269/mrdoc/pdf/5269tech nicalreport.pdf

29. Grantham-McGregor S.M, Powell CA, Walker SP, Himes JH. Nutritional supplementation, psychosocial stimulation, and mental development of stunted children: the Jamaican Study. Lancet. 1991 Jul 6;338(8758):1-5. http://dx.doi.org/10.1016/0140$\underline{6736(91) 90001-6}$

30. Gertler P, Heckman J, Pinto R, Zanolini A, Vermeersch C, Walker S, et al., Labor market returns to an early childhood stimulation intervention in Jamaica. Science. 30 May 2014;344(6187):9981001. http://dx.doi.org/10.1126/science.1251178

31. Sparlingn, J. A working document on the Abecedarian educational program and its probable relationships to child outcome behaviors. Human Capital and Economic Opportunity Working Group Economic Research Center, University of Chicago. 2011 Dec. Available from http://econresearch.uchicago.edu/sites/econresearch. uchicago.edu/files/Sparling_2011_working-abc.pdf

32. Campbell F, Conti G, Heckman JJ, Moon SH, Pinto R, Pungello E, et al. Early childhood investments substantially boost adult health. Science. 2014 March 28;343(6178):1478-85. http://dx.doi.org/10.1126/science.1248429

33. Ramey CT, Sparling JJ, Ramey SL. Abecedarian: the ideas, the approach, and the findings. Los Altos, CA: Sociometrics Corporation; 2012.

34. Schweinhart L J, Montie, J, Xiang, Z, Barnett WS, Belfield CR, Nores M, et al. Lifetime effects: the high/scope Perry preschool study through age 40. Ypsilanti, MI: High/Scope Press, 2005.

35. Vogel CA, Xue Y, Moiduddin EM, Carlson BL. Early head start children in grade 5: long-term follow-up of the early head start research and evaluation study sample. OPRE Report \# 2011-8, Washington, DC: Office of Planning, Research, and Evaluation, Administration for Children and Families. U.S. Department of Health and Human Services. 2010.

36. Berlin L J, Dodge KA, Reznick JS. Examining pregnant women's hostile attributions about infants as a predictor of offspring maltreatment. JAMA Pediatr. 2013 June;167(6):549-53. http://dx.doi.org/10.1001/jamapediatrics.2013.1212

37. Lamb ME. How do fathers affect children's development? Let me count the ways. In M E Lamb, editor. The role of the father in child development (5th ed., pp. 1-26). Hoboken, NJ: Wiley. 2010.

38. Grimalt L, Heresi E.2012. Estilos de apego y representaciones maternas durante el embarazo [Spanish] [Translation: Attachment style and maternal representations during pregnancy]. Rev Chile Pediatr 2;83(3):239-46.

39. Flykt M. Prenatal representations predicting parentchild relationship in transition to parenthood. Tampere: Tampere University Press; 2015. Available from:

https://tampub.uta.fi/bitstream/handle/10024/95679/9 78-951-44-9503-8.pdf?sequence $=1$

40. Rosenblum K L, McDonough SC, Sameroff AJ, Muzik M. Reflection in thought and action: maternal parenting reflectivity predicts mind-minded comments and interactive behavior. Inf Ment Hlth J. 2008;29:362-76.

http://dx.doi.org/10.1002/imhj.20184

41. Arnott B, Meins E. Links between antenatal attachment representations, postnatal mindmindedness, and infant attachment security: a preliminary study of mothers and fathers. B Menninger Clin. 2007;71:132-49. http://dx.doi.org/10.1521/bumc.2007.71.2.132

42. Alhusen JL, Hayat MJ, Gross D. A longitudinal study of maternal attachment and infant developmental outcomes. Arch Womens Ment Hlth. 2013;16(6):521-9. http://dx.doi.org/10.1007/s00737013-0357-8

43. Nishikawa M, Sakakibara HE. Effect of nursing intervention program using abdominal palpation of Leopold's maneuvers on maternal-fetal attachment. Reprod Hlth.2013;10:12. http://dx.doi.org/10.1186/1742-4755-10-12

44. Bellieni CV, Ceccarelli D, Rossi F, Buonocore, Maffei M, Perrone S, et al. Is prenatal bonding enhanced by prenatal education courses? Minerva Ginecol. 2007 April;59(2):125-9.

45. Abasi E, Tafazzoli M, Esmaily H, Hassanabadi H. The effect of maternal-fetal attachment education on maternal mental health. Turk J Med Sci. 
2013;43(5):815-20. http://dx.doi.org/10.3906/sag$\underline{1204-97}$

46. Kiang L, Moreno AJ, Robinson JL. Maternal preconceptions about parenting predict child temperament, maternal sensitivity, and children's empathy. Dev Psychol. 2004;40(6):1081-92. http://dx.doi.org/10.1037/0012-1649.40.6.1081

47. Condon JT, Corkindale CJ, Boyce P. Assessment of postnatal paternal-infant attachment: development of a questionnaire instrument. J Reprod Infant Psych. 2008;26(3):195-210. http://dx.doi.org/10.1080/02646830701691335

48. Shonkoff JP. [Co-Chair, INBRIEF] The foundations of lifelong health [presentation to Westchester Children's Association]. March 24, 2006; New York. National Scientific Council on the Developing Child and the National Forum on Early Childhood Policy and Programs. Center on the Development of the child, Harvard University.

49. Shonkoff JP. No Time to lose: closing the gap between what we know and what we do. [Slide show]. [Presentation to Westchester Children's Association]. 2006 March 24. Available from: http:// http://www.slideserve.com/ksena/no-time-to-loseclosing-the-gap-between-what-we-know-and-whatwe-do

50. Felitti VJ, Anda RF, Nordenberg D, Williamson DF, Spitz AM, Edwards V, et al. The relationship of adult health status to childhood abuse and household dysfunction. Am J Prev Med. 1998;14:245-58. http://dx.doi.org/10.1016/S0749-3797(98)00017-8

51. Felitti VJ, Anda, RF, Nordenberg MD, Williamson MS, et. al. Relationship of childhood abuse and household dysfunction to many of the leading causes of death in adults. Amer J Prev Med, 1998; 14(4): 245 - 258. http://dx.doi.org/10.1016/S07493797(98)00017-8

52. Anda RF, Brown DW, Felitti VJ, Bremmer JD, Dube SR, Giles WH. Adverse childhood experiences and prescribed psychotropic medications in adults. Amer J Prev Med, 2007 May; 32(5): 389-94. http://dx.doi.org/10.1016/j.amepre.2007.01.005

53. Perry B.D, Szalavitz M. Born for love: why empathy is essential--and endangered. New York, NY: HarperCollins Publishers; 2010.

54. Bornstein MH, editor. Maternal responsiveness: characteristics and consequences. San Francisco: Jossey-Bass; 1989.
55. Cozolino L. The neuroscience of human relationships: attachment and the developing social brain. $2^{\text {nd }}$ ed. New York \& London: W.W. Norton \& Company; 2012.

56. Knafo A, Zahn-Waxler C, Van Hulle C, Robinson JL, Rhee SH. The developmental origins of a disposition toward empathy: genetic and environmental contributions. Emotion. 2008 Dec. 8(6): 737-52. http://dx.doi.org/10.1037/a0014179

57. Kiang L, Moreno AJ, Robinson JL. Maternal preconceptions about parenting predict child temperament, maternal sensitivity, and children's empathy. Dev Psych. 2004;40:1081-92. http://dx.doi.org/10.1037/0012-1649.40.6.1081

58. Lahey, B. B., Van Hulle, C. A., Keenan, K., Rathouz, P. J., D’Onofrio, B. M., Rodgers, J. L., et al. 2008). Temperament and parenting during the first year of life predict future child conduct problems. Journal of Abnormal Child Psychology, 36, 1139-58. http://dx.doi.org/10.1007/s10802-0089247-3

59. Davidov M, Grusec JE. Untangling the links of parental responsiveness to distress and warmth to child outcomes. Child Devel. 2006 Jan-Feb;77(1):4458.

60. Volbrecht MM, Lemery-Chalfant K, Aksan N,ZahnWaxler C, Goldsmith HH. Examining the familial link between positive affect and empathy development in the second year. J Gene Psych. 2007;168(2),105-29. http://dx.doi.org/10.3200/GNTP.168.2.105-130

61. Lévy F, Gheusi G, Keller M. Plasticity of the parental brain: a case for neurogenesis. $\mathrm{J}$ Neuroendocrinol. 2011 Nov; 23(11):984-93. http://dx.doi.org/10.1111/j.1365-2826.2011.02203.x

62. Mak GK, Weiss S. Paternal recognition of adult offspring mediated by newly generated CNS neurons. Nat Neurosci.2010 Jun;13(6):753-8. [Epub, 2010 May 9] http://dx.doi.org/10.1038/nn.2550.

63. Leuner B, Glasper ER, Gould E. Parenting and plasticity. Department of Psychology and Neuroscience Institute, Princeton University, Princeton NJ 08544, USA. October; 33(10):465-73. http://dx.doi.org/10.1016/j.tins.2010.07.003.

64. Horstman,J. The Scientific American book of love, sex and the brain: the neuroscience of how, when, why and who we love. San Francisco, CA: JosseyBass; 2011. 
65. Mossop B. The brains of our fathers: does parenting rewire dads? Fathers and their children reshape one another's neurons. Sci Am. 2010 Aug 17. Available from:

https://www.scientificamerican.com/article/thebrains-of-our-fathers/

66. Raeburn P. Do fathers matter? What science is telling us about the parent we've overlooked. New York, NY: Sci Am / Farrar, Straus and Giroux; 2014,

67. Lambert KG. The parental brain: transformations and adaptations. Physiol Behav. 2012 Mar. http://dx.doi.org/10.1016/j.physbeh.2012.03.018

68. Mossop B. How dads develop. When men morph into fathers, they experience a neural revival that benefits their children. Sci Am Mind. July/August 2011.

69. National Scientific Council on the Developing Child. Shonkoff JP, Chair. The science of early childhood development. National Scientific Council on the Developing Child. 2007 [p.3].

70. Evans GW, Brooks-Gunn J, Klebanov PK, Stressing out the poor: chronic physiological stress and the income-achievement gap. Pathways. 2011 Winter.

71. Vegas E, Santibañez L. The promise of early childhood development in Latin America and the Caribbean. Washington, DC: World Bank; 2010.

72. Britto P, Yoshikawa H, Boller K. Quality of early childhood development programs and policies in global contexts: rationale for investment, conceptual framework and implications for equity. Social Policy Reports of the Society for Research in Child Development. 2011.

73. Noble KG, Houston SM, Brito NH, Bartsch H, Kan E, Kuperman JM, et al. Family income, parental education and brain structure in children and adolescents. Nat Neurosci. [advance online publication].2015. http://dx.doi.org/10.1038/nn.3983

74. Task Force on the Family/American Academy of Pediatrics. Family Pediatrics [report] June 2003; 111(2):1541. Available from: http://pediatrics.aappublications.org/content/111/Sup plement $2 / 1541$

75. Losada L.S., De Angulo J.M. et al. Las 12 Estrategias para El Desarrollo Integral de la Infancia [The 12 strategies for integral development in infancy]. MAP International. 2013. Available from http://www.iin.oea.org/pdfiin/RH/12_Estrategias_Desarrollo_Integral_Infancia Temprana.pdf

76. National Child and Material Health Intelligence Network. Social justice begins with babies: the first annual report of Scotland's coalition supporting Putting the Baby IN the Bath Water. [Published: 2014 December 04]. Available from http://www.chimat.org.uk/resource/item.aspx?RID=2 29418

77. Heckman JJ, Masterov DV. The productivity argument for investing in young children. [Discussion Paper No. 2725]. Rev of Agri Econ. 2007;29(3):446-93. Available from: http://www.iza.org/en/webcontent/publications/paper s/viewAbstract?dp id=2725

78. Mehta NB, Hull AL, Young JB.. Just Imagine: New Paradigms for Medical Education. Acad Med. 2013 Oct;88(10):1418-23. http://dx.doi.org/10.1097/ACM.0b013e3182a36a07

79. De Angulo J., M. The Church empowered. In: A new agenda for a medical mission. Ewert EM, editor. MAP International Monograph.

80. Canadian Best Practices Portal. Key Element 4: Increase Upstream Investments. [Internet] Public Health Agency of Canada. Available from: http://cbpp-pcpe.phac-aspc.gc.ca/population-healthapproach-organizing-framework/key-element-4increase-upstream-investments/

81. A Rolnick, Grunewald R. Early childhood development: economic development with a high public return. The Region. 2003;17(4):6-12.

82. Rolnick AJ, Grunewald R. Early childhood development is high-return economic development. Children \& Families Subcommittee Health Education, Labor, and Pensions (HELP) Committee. 2011. Available from: http://www.help.senate.gov/imo/media/doc/Rolnick. pdf

83. Boff L. Aforismos [Internet] Koinonia. 2008. Available from: http://www.servicioskoinonia.org/boff/articulo.php?n $\mathrm{um}=257$ 
Peer Reviewed

Competing Interests: None declared.

Correspondence: Jose Miguel De Angulo, MAP International, Plurinational State of Bolivia. mapbol@verizon.net

Cite this article as: De Angulo JM, Losada LS. The emerging health paradigm in the 21st century: The formative first 1000 days of life. Christian Journal for Global Health (Nov 2016), 3(2):113-128.

(C) De Angulo JM, Losada LS This is an open-access article distributed under the terms of the Creative Commons Attribution License, which permits unrestricted use, distribution, and reproduction in any medium, provided the original author and source are properly cited. To view a copy of the license, visit http://creativecommons.org/licenses/by/4.0/

wWw.cjgh.org

Nov 2016. Christian Journal for Global Health, 3(2): 113-128. 